\title{
VIRTUAL REALITY-SUPPORTED DRILLING STRATEGY IN TEACHING ENGLISH VOCABULARY TO YOUNG LEARNERS
}

Halimah $^{1}$, Vina Nurviyani ${ }^{2}$, Asep Saepulah ${ }^{3}$, Jauhar Helmie ${ }^{4}$, Rahmi Wulandari Wandawati ${ }^{5}$

1,2,3,4,5 Universitas Suryakancana Cianjur

Email: halimahsmart@yahoo.com

\begin{abstract}
This present research intent to discover the implementation of Virtual Reality (VR) media in supporting drilling strategy to teach English vocabulary to young learners modeled by a current teacher who is taking Independent Learning-Campus Merdeka (Merdeka Belajar-Kampus Merdeka or MBKM) as the participant of this study. She is holding a responsibility to teach English lesson to a school partnership. The school that is in partnership is Trikarya Public Elementary School of Cipanas district. This research collected the data through observation on teaching praxis using VR media. As the data were collected, the writer analyzed them. There were six steps in analyzing the data; (1) preparing the data to be analyzed, (2) reading or viewing all data, (3) coding the data, (4) generalizing the code, (5) creating tables based on the data code, and (6) interpret the data code. Over the observation the writers found a new procedure on implementing VR media in teaching English vocabulary to elementary students. There are three stages in this procedure that is called PMP. PMP stands for Pre-Activity, Main Activity, and Post-Activity. Furthermore, there are four activities in the main stage; Watch, Collect, Sharing, and Practice and hereafter is called WCSP. The last finding uncovers that the teacher is using drilling as the teaching strategy to activate the students.
\end{abstract}

Keywords: drilling, young learners, virtual reality, vocabulary (c) (1)

\section{INTRODUCTION}

\subsection{Introduction}

Independent Learning or freedom to learn (Prahani et al., 2020) - Campus Merdeka is a policy of the Minister of Education and Culture which aims to encourage students to master various sciences to enter the world of work. The Independent Learning Policy-Independent Campus is in accordance with Permendikbud Number 3 of 2020 concerning National Higher Education Standards. In the view of humanism, independent learning provides opportunities for students to learn autonomously or independently and be responsible for themselves. Students have the right to take part in learning outside the study program on campus and outside campus in various activities such as student exchanges, internships/work practices, teaching assistance in 
education units, research, humanitarian projects, entrepreneurial activities, independent studies/projects, and building villages/Real Work Courses Thematic (KKNT). The involvement of students in these activities can provide a learning experience as a provision to face life and life in the future. To realize this learning experience, universities must build cooperation with the business/industry world and the government.

The presence of the Minister of Education and Culture's policy in 2020 with the Merdeka Learning Campus Merdeka (MBKM) has created a new paradigm in the world of education, including higher education. The premise of the Independent Learning Campus Merdeka (MBKM) implies independence and freedom for educational institutions, both in state universities and in private universities. According to Nadiem Makarim, the basic concept of choosing independent learning was inspired by the philosophy of K.H. Dewantara with an emphasis on independence and independence. Merdeka Learning Merdeka Campus (MBKM) is considered relevant and appropriate to be implemented in the current democratic era. The definition of independence here can be applied in the educational process such as in the lecture process at universities, students choose eight independent learning programs offered by the ministry, where students are given the opportunity to attend lectures outside the study program in the same university for one semester or the equivalent of 20 credits (Fuadi \& Aswita, 2021). This program is expected to be able to improve the competence of graduates, both soft skills and hard skills, to be more prepared and relevant to the needs of the times and also to prepare graduates as future leaders of the nation who are superior, moral and ethical (Simatupang \& Yuhertiana, 2021).

Suryakancana University is one of the universities that is conducting Independent Learning- Campus Merdeka in collaboration with some companies and schools surrounding as the partnerships. One of the school partnership is Trykarya Public Elementary School which is located in Cipanas district. Here, the students of Merdeka Belajar are holding a responsibility to teach English lesson. Although by the changing of curriculum of KTSP (Kurikulum Tingkat Satuan Pelajaran) to Curriculum 2013 where in this curriculum English lesson is excluded for they think that as Indonesian citizen learning Bahasa Indonesia as the first and national language is more important for young learners at elementary than English (Zamzami, 2019). In other hand, some stated that it is also important for young learners to learn English for it is an international language that should be learnt by everyone in the world. Then, Elementary School is the right level to start introducing English as foreign language because of the students' golden age. They will get easier to learn this subject in the next school levels. This issue still invites many controversies from many education experts and still being unresolved issue (Nufus, 2019). Yet, it also needs to be consider that educators of this era should prepare the young generation to have the $21^{\text {st }}$ century skills in order to be able to compete with others. One of those skills is mastering the world language e.g. English.

As an effort to introduce English as a world language, in elementary schools, English lessons are not compulsory subjects but are included in the curriculum as local content (Meisani, 2018). Despite its existence as a local content, English lessons are quite a challenge for elementary school teachers.

Regarding to the importance of the best age for learning language, some linguists believe that universal grammar and its interactions with the rest of the brain are the design mechanisms 
that allow children to become fluent in any language during their first few years of life. In fact, childhood may be a critical period for the development of language skills (Sepyanda, 2017). Some scientists believe that if a person does not learn a language before the age of adolescence, they will never learn it in a functional sense. Children may also have a greater ability to learn second languages than adults, especially in natural settings (Prihatin, 2017); (Nufus, 2019). Yet, teaching English for young learners of elementary school is not easy task. There are some problems encountered by the teachers and the students.

In contrast to English lessons in junior and senior high schools, the objectives of learning English in elementary schools are not clearly formulated so that teachers do not have clear guidelines in teaching. This makes teachers teach more based on personal beliefs and understanding. while in reality the teacher does not have a linearity in teaching English to elementary school students. This is one of the obstacles faced by teachers in teaching English.

Nevertheless, since the curriculum of Kurikulum Tingkat Satuan Pelajaran that wellknown as KTPS was changed with Curriculum 2013 or $K-13$ the subject of English at elementary school level was not belong to the compulsory subject to be taught at was recognized as Muatan Lokal, the students had known English for their starting before entering Junior High School that have more complicated material. It was excluded from KTSP (Diyanti, Nurhayati, \& Supriyanti, 2020). K-13 focuses on Bahasa Indonesia rather than English for they think that Bahasa Indonesia is more important than English (Sepyanda, 2017).

Concerning to the issue mentioned above, the writers agree that English is important to be taught in the early age especially on the age of elementary school. It is good for the students to get the preliminary English subject before they are entering to the secondary levels where the contents of the subject are more complicated. By having the introductory subject, the students will more adaptable in learning English on the upper level.

As it has been mention in the introductory stage, this research aims to uncover the result of the observation on the teacher who is taking Independent Learning-Campus Merdeka program praxis in executing the drilling strategy supported by VR media in teaching English vocabulary to young learners.

Since currently we are living in an advanced technology era where the advances in information and communication technology have ushered in a period of transformation in many areas of life, including education, the presence of media in the learning process has a considerable importance in uncovering the ambiguity and complexity of the subject matter. The use of technology in education will resolve the constraints of space and time, disseminate information more easily and efficiently, and ensure that the communication delivered is in accordance with the learning objectives. $21^{\text {st }}$ century teachers should have competence in using various technology products as media to deliver educational services (Muchtar, Nasrah, \& Ilham, 2021); (Nurmala, Triwoelandari, \& Fahri, 2021).

Media has an important role as an intermediary in the delivery of learning materials, for example interactive media. This media is a very significant learning component. The use of media in the classroom can have a very large positive impact on the student learning process. Furthermore, learning media is an important foundation that functions as a complement and a vital part of the success of the learning process (Wulandari, Widyaningrum, \& Arini, 2021). 
Based on the type, the researchers distinguish the types of learning media that can be used as learning aids. In general, learning media are divided into seven, namely students, realia, pictures, textbooks, whiteboards, OHP, flipcharts, and technology-based media. Other experts say that there are three types of learning media; print, digital, and electronic (Joseph B., 2016). Other types of learning media are print and non-print media (Surbhi, 2017). Based on the type, in this study the learning media used as a tool in triggering students' interest in English is a technology-based learning media in the form of an application called "Virtual Reality" (Figure 1).

By definition, virtual reality, or commonly known as VR, is a three-dimensional technology that is immersive, realistic, and can provide real experiences to activate and engage passive students. Virtual Reality can bring reality to the classroom because of the environment in which Virtual Reality can be built. Related to the increasingly widespread use of Virtual Reality in the 21st century (Utami, Suwastini, Dantes, Suprihatin, \& Adnyani, 2021).

Virtual Reality media can be applied in various fields, one of which is in the field of education which can be used as learning media to support the learning process. Interestingly, Virtual Reality media to be applied to this research is to provide new learning experiences for children and provide something interesting activities where children will be directly involved to see a pseudo world which are actually dynamic images so that children feel as if they are as if in the real world (Dharma, Sugihartini, \& Arthana, 2018). By using VR media students will be stimulated to learn so that learning objectives can be achieved optimally. This is in line with the expression conveyed by (Sari, Suryanti, \& Manurung, 2017) that a good learning media must support the achievement of maximum learning. The media was chosen with the aim of increasing learner motivation. In addition, the media must also stimulate students to remember what they have learned in addition to providing new learning stimuli. Good media will also activate students in providing feedback, feedback, and encouraging students to do the exercises correctly.

Research on the use of VR has been carried out by several researchers. Among them the research conducted by (Dharma et al., 2018) on early childhood (PAUD) who found that there was an effect of using virtual reality media on student learning outcomes. Other researchers have revealed that the use of virtual reality provides several benefits in authentic learning in 21st century language classes (Utami et al., 2021); (Andre, Handriyantini, \& Oktavia, 2019) in their research conclusion stated that virtual reality technology can be implemented into an educational game on the android platform by using Unity 3D as the game engine.

Even though technology is created and presented to provide convenience in various lines of life, including education, there will be no benefit if we do not know how to use it. To get optimal benefits from technology, teachers must be able to mix and mix the technology with strategic steps so that the goals to be achieved can be achieved properly (Dewi, Halimah, \& Kurniawati, 2021).

\subsection{Research questions}

How is the implementation of Virtual Reality in teaching of English to the elementary school students of SDN Trykarya to support the drilling teaching strategy? 


\subsection{Significance of the study}

Theoretically, pedagogically, and practically, the findings of this study are expected to benefit English teachers, students, and future researchers. Theoretically, the findings of this study inform teachers about the importance of teaching media strategy in vocabulary instruction and suggest that the Virtual Reality can be used as an alternative media in supporting the teaching strategy to teach students' English vocabulary. Meanwhile, through the implementation of Virtual Reality in learning process the pupils have got an experience in learning and the group work promote the students' socioemotional skill. The drilling strategy can make the students not only know how to pronounce the words correctly, but you must also understand the true meaning of the words and how to use them in a proper sentence. This study has the potential to have a positive impact on education from a pedagogical standpoint. Practically, the researcher supposes that the study will contribute knowledge to the development of English vocabulary through the use of the media technology and will serve as a reference for those who wish to conduct research on teaching vocabulary.

\section{METHOD}

\subsection{Research Design}

The purpose of this study is to report how Virtual Reality is the implemented in teaching of English vocabulary to the elementary school students of SDN Trykarya to support the drilling teaching strategy. With this specific aim, the researcher wants to describe how drilling strategy and Virtual Reality are applied together in the English vocabulary class. Therefore, this study applied qualitative descriptive method.

\subsection{Participants}

The study was conducted at SDN Trykarya Cipanas in the academic year 2021. This researcher was conducted from $21^{\text {st }}$ Desember 2021 until $23^{\text {rd }}$ December 2021. The participant consisted of an English teacher who is taking Independent Learning-Campus Merdeka program.

\subsection{Instruments}

This research collected the data from observation. To answer the question, the researchers observed the implementation of Virtual Reality Media as a supported media in the classroom.

\subsection{Data analysis}

As the data were collected, the writer analyzed them. There were six steps in analyzing the observation as well as the questionnaire: (1) preparing the data to be analyzed, (2) reading or viewing all data, (3) coding the data, (4) generalizing the code, (5) creating tables based on the data code, and (6) interpret the data code (The Alberta Teacher's Association, 2000), (Creswell, 2012) in (Halimah, Ibrahim, \& Lustyantie, 2019).

\section{FINDINGS AND DISCUSSION}

\subsection{Findings}

Virtual Reality Media Supported Drilling Technique in Teaching English Vocabulary to Young Learners

Over the observation on the lesson plan and its implementation in the classroom, it can be noted that in implementing Virtual Reality as a teaching media in teaching English to young 
learner the teacher used Drilling strategy. The teaching activities involved three phases namely Pre-Activity, Main Activity, and Post-Activity (PMP). In the main phase there are four main activities; watching, collecting, sharing, and practicing. Those phases are presented in the following table.

Table 1. The Teaching English Vocabulary Procedure Using Drilling Strategy Supported by Virtual Reality Media

\begin{tabular}{ll}
\hline \multicolumn{1}{c}{ Stages } & \multicolumn{1}{c}{ Activities } \\
\hline 1. Pre-Activity & 1) the teacher opened the class by greeting the students and asking \\
their condition, 2) the teacher invited the students to do opening \\
prayer, 3) the teacher called the role to make sure the students' \\
presence, 4) the teacher asked students some questions for brain \\
storming, 5) the teacher introduced the students the teaching material \\
and connected the material with the students' real life, and 6) the \\
teacher informed and simulated the use of VR to the students.
\end{tabular}

2. Main-Activity 1) watching video through Virtual Reality media, 2) collecting some vocabulary from the video, 3 ) sharing the vocabulary they got from the video, and 4) practice using the vocabulary they got.

3. Post-Activity 1 1) the teacher asked the students to retell things related with the teaching and learning they passed at that day, 2) the teachers also gave the students some questions about the material they have just learned, 3) the teacher motivated the students to learn more at home, 4) the teacher invited the leader of the class to lead the class praying, and 5) the teacher thanked and said goodbye to the students.

\subsection{Discussion}

From the result of the observation it is shows that the teacher used drilling strategy in teaching vocabulary to the elementary students. In implementing this strategy, the teacher used Virtual Reality as the teaching media to support the teaching and learning activities. The brief activities conducted during the implementation of this strategy is narrated in the following part.

\section{Pre-Activity Stage}

In the Pre-Activity the teacher accomplished some activities; 1) the teacher opened the class by greeting the students and asking their condition, 2) the teacher invited the students to do opening prayer, 3) the teacher called the role to make sure the students' presence, 4) the teacher asked students some questions for brain storming, 5) the teacher introduced the students the teaching material and connected the material with the students' real life, and 6) the teacher informed and simulated the use of VR to the students (Figure 1). 


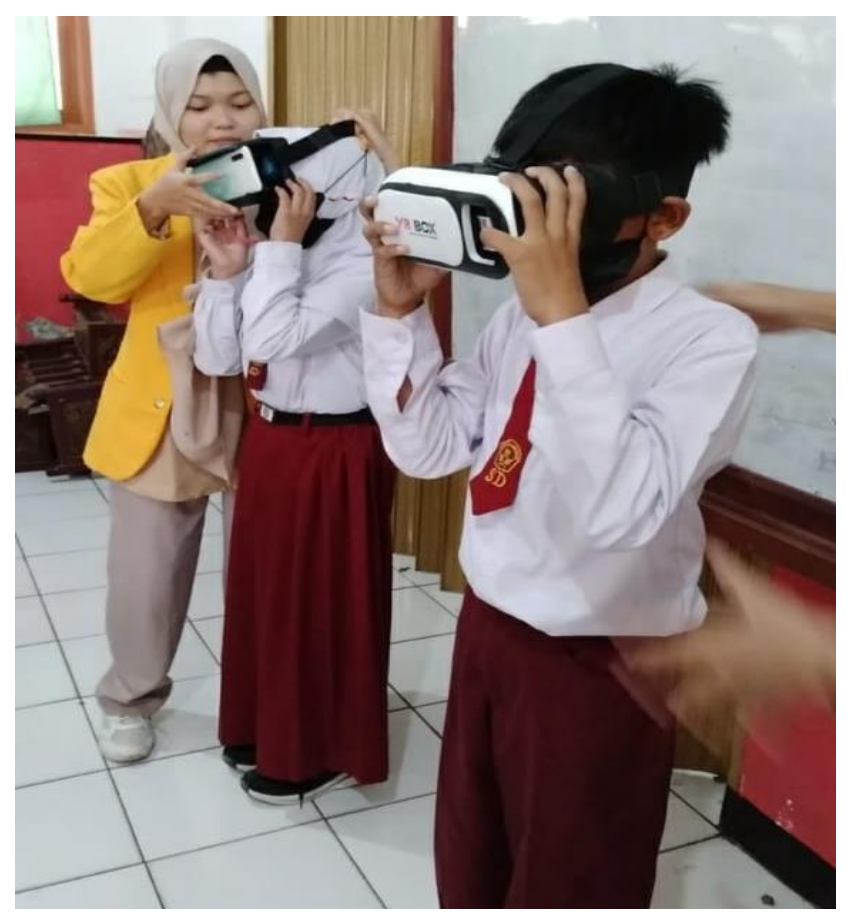

Figure 1. The Sample of Photo of Simulation of

Using Technology in the classroom

In every teaching and learning process it should be opened with the initial activities. These activities are carried out by the teacher to create an atmosphere of students' readiness and gathered students' attention to focus on the things to be learned. The activity of opening the lesson is an activity prepare students to enter the core activities (main activities) closing the lesson is activities to solidify or follow up on the topics to be discussed. The component of opening lesson skills consists of attracting students' attention, motivation, giving references through various efforts, and making links or relationships between the materials to be studied. The specific purpose of opening the lesson is the emergence of students' attention and motivation to deal with learning tasks that will be done; students know the limits of the task will be done; students have a clear picture of possible approaches taken in studying parts of the subject matter; students know the relationship between experiences that have been mastered with new things to be learned or unfamiliar; students can relate the facts, skills or concepts listed in an event; and students can find out the level of success in learning the lesson, while the teacher can know the level of success in teaching (Sundari \& Muliyawati, 2017).

\section{Main Activity Stage}

There are four activities in the main stage; 1) watching video through Virtual Reality media, 2) collecting some vocabulary from the video, 3) sharing the vocabulary they got from the video, and 4) practice using the vocabulary they got.

In watching the video, the students use VR media. The use of video has been shown to help learners improve their ability to identify sound and words (Simanullang, 2018); (Sanjadireja, 2020); (Hariyono, 2020). Virtual Reality media applied to this research is to provide new learning experiences for children and provide something interesting activities where children will be directly involved to see a pseudo world which are actually dynamic 
images so that children feel as if they are as if in the real world (Dharma et al., 2018). By using VR media students were stimulated to learn so that learning objectives can be achieved optimally. This is in line with the expression conveyed by Sari, Suryanti, \& Manurung (2017) that a good learning media must support the achievement of maximum learning. The media was chosen with the aim of increasing learner motivation. In addition, the media must also stimulate students to remember what they have learned in addition to providing new learning stimuli.

The second activity was collecting information from the video. Expert said that when using VR students collected more information in the same amount of time it would take to do physical experiments (Yildirim, Topalcengiz, Arikan, \& Timur, 2020). When students use video film themselves they are given potential to create something memorable and enjoyable. In addition, students will be enjoying their learning activity. Video film can help them to achieve in understanding the material (Devanti, 2018). Moreover, by watching the video eased the student to collect and memorize words related to the video.

The third activity was sharing. In in stage the students share their experience with their friends within the group (Figure 2). This activity promotes the students to work collaboratively and cooperatively with their friends. Grouping the pupils promotes the dialogue between the peers in the group. It is good for them to learn how to solve the task in group. It also builds a positive socioemotional ethos within the group (Veldman, Doolaard, Bosker, \& Snijders, 2020).

The last activity was practice. The activities the students did in the practice phase were 1) imitated the teacher in pronouncing the words. It was the time for the teacher to drill the students to pronounce the words appropriately, 2) arrange the alphabets become a meaningful word. In this stage the students learned how to spell the words and write the words they have learned. Here the students learned how to write the English words, and 3) pronounce the word in an appropriate way. This activity promoted the students to speak in English.

In the repetition drill, the students repeat teacher's model as quickly and accurately as possible. They listen to a model, provided by the teacher, or a tape or another student, and repeating what is heard. The drill method is an activity to do the same thing, repeatedly in earnest with the aim of strengthening an association or perfecting a skill to become permanent. Drill is a teaching model where each student or student carries out training activities to become more agile and skilled. So this method is an activity in the form of repeated repetitions of the same thing. (Fivy Andries, 2019). 


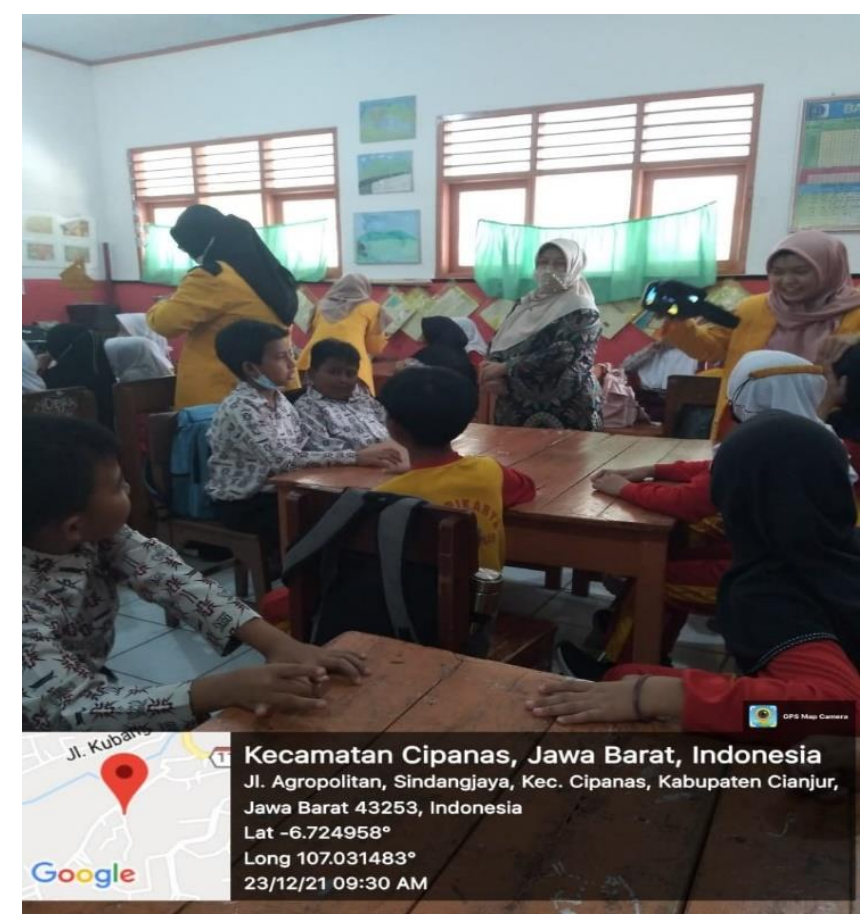

Figure 2. The Sample of Photo the Students Work Collaboratively with their Friends and Teachers

\section{Post-Activity Stage}

In the post activity the teacher reviewed the teaching and learning process; 1) the teacher asked the students to retell things related with the teaching and learning they passed at that day, 2) the teachers also gave the students some questions about the material they have just learned, 3) the teacher motivated the students to learn more at home, 4) the teacher invited the leader of the class to lead the class praying, and 5) the teacher thanked and said goodbye to the students. In learning vocabulary, it is the teacher responsibility to motivate students to understand the meaning of vocabulary are learned in the classroom, not only to be understood at that moment, but also to remember onwards in longer time and used in a sentence (Dewi et al., 2021).

In the teaching and learning process, post activity is also known as closing activity. The ability to close the lesson was become one of teacher competence indicators (Sundari \& Muliyawati, 2017). Overall finding from the observation on teaching processes is presented in the following chart. 


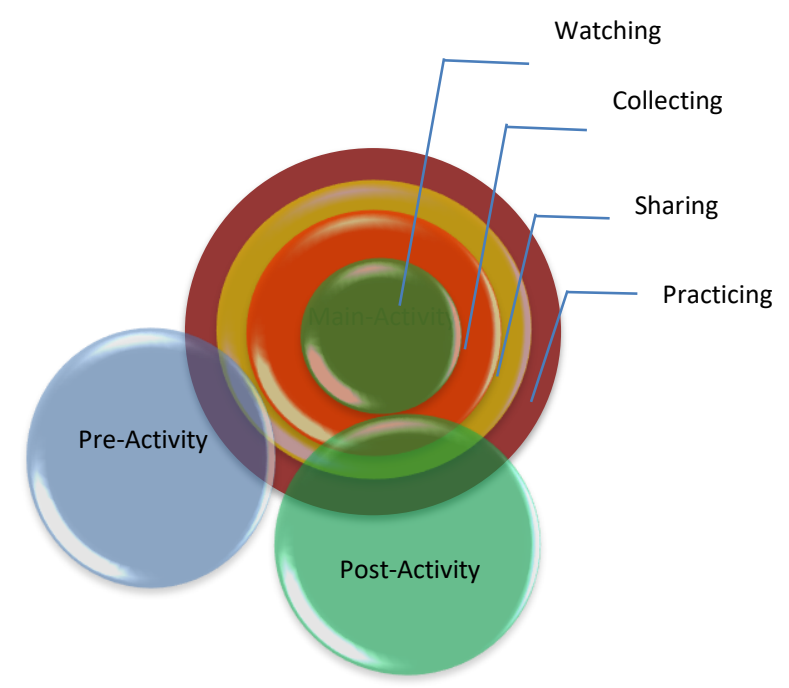

Chart 1. Teaching Procedure Using VR Media for English Vocabulary

From the observation it also could be described that the students were very excited in participating English class using Virtual Reality in the classroom. It is supported by Dewi et al. (2021) that when the students study in fun and joy condition the goal of teaching and learning will be gained effectively. They students worked collaboratively with their friends, delivered their ideas and opinion without feeling of fright.

\section{CONCLUSIONS}

\subsection{Conclusion}

It is the fact that in Indonesia English is not a compulsory subject to be taught at elementary school. Even more, this subject was excluded from the K-13. Nevertheless, we have to be aware that mastering English as one of international language is undeniable. As educators, we have to prepare the young generation to have a competitive skill in facing the global world. One of them is by mastering English. As English is a foreign language in Indonesia, learning it as early stage as possible is suggested by the linguists. It is because the learners will absorb the new language easier when they learn on the early age. Yet, it also became a dilemma for the teachers of elementary school when they have to teach English in the classroom. The reason was because they didn't have any English background knowledge. So they found difficulties on the preparing the teaching material, selecting the appropriate strategy, and choosing the suit media. Through the result of this community service program it is hoped will give the idea to the elementary English teacher to conduct the teaching practices better.

\subsection{Suggestions}

Based on the finding and conclusion of this research, it can be suggested that there needs to be an improvement in the English learning method which was originally still manual but now shifts to the use of technological tools, by providing a solution that can be offered is to provide reinforcement to the trainee teachers that collaborative-based learning can be applied when VR is used as a tool of instructional Media. 


\section{Acknowledgments}

We express our deepest gratitude to the Ministry of Education, Culture, Research, and Technology of the Republic of Indonesia, for the funding assistance for the research program for independent learning policies on independent campuses and community service based on research results and prototypes of private universities. We would also like to thank a number of parties who have assisted in the successful implementation of this activity, namely:

1. Directorate General of Higher Education Research and Technology

2. Cianjur District Education Office;

3. Trykarya Elementary School English Teachers in Cipanas District, Cianjur;

4. Rector of Suryakancana University;

5. Vice Chancellor 1, 2, 3 Suryakancana University;

6. The academic community at Suryakancana University; and

7. The entire team implementing this activity.

Hopefully the institutional cooperation that has been established so far will increase and may Allah SWT always bestow His grace, taufik, and guidance to all of us. Amen.

\section{REFERENCES}

Andre, J. L., Handriyantini, E., \& Oktavia, C. A. (2019). Pengembangan Game Virtual Reality Berbasis Android Menggunakan Unity Sebagai Media Penunjang Pengenalan Bahasa Inggris. J-Intech, 6(02), 208-213. https://doi.org/10.32664/j-intech.v6i02.253

Devanti, Y. M. (2018). The Use of Video as a Media to Improve Students' Vocabulary Mastery. ELLITE: Journal of English Language, Literature, and Teaching, 3(1), 42. https://doi.org/10.32528/ellite.v3i1.1778

Dewi, L. O., Halimah, \& Kurniawati, N. (2021). The Merit of Guessing Game in Imptoving Students’ Vocabulary Matery. Journal of Teaching and Education, 3(2), 294-309. Retrieved from http://journals.umkt.ac.id/index.php/acitya

Dharma, K. Y., Sugihartini, N., \& Arthana, I. K. R. (2018). Pengaruh Penggunaan Media Virtual Reality Dengan Model Pembelajaran Klasikal Terhadap Hasil Belajar Siswa Di Tk Negeri Pembina Singaraja. Jurnal Pendidikan Teknologi Dan Kejuruan, 15(2), 298-307. https://doi.org/10.23887/jptk-undiksha.v15i2.14481

Diyanti, Y., Nurhayati, L., \& Supriyanti, N. (2020). The Profile of Primary English Teachers in Indonesia. LITERA, 10(1), 37-51.

Fivy Andries, F. (2019). the Use of Drill Techniques in Teaching Present and Past Tense Private Grammar Toward Students in English Study Program of Unima. Journal of English Language and Literature Teaching, 4(1), 59-66. https://doi.org/10.36412/jellt.v4i1.944

Fuadi, T. M., \& Aswita, D. (2021). Merdeka Belajar Kampus Merdeka (Mbkm): Bagaimana Penerapan Dan Kedala Yang Dihadapi Oleh Perguruan Tinggi Swasta Di Aceh. Jurnal Dedikasi Pendidikan, 5(2), 603-614. Retrieved from http://jurnal.abulyatama.ac.id/index.php/dedikasi 
Halimah, Ibrahim, G. A., \& Lustyantie, N. (2019). Technology CLL to Foster Student's Speaking. In Proceedings of the International Conference on Industrial Engineering and Operations Management (pp. 2389-2399). Pilzen: IEOM Society International.

Hariyono, T. C. (2020). Teaching Vocabulary To Young Learner Using Video on Youtube At English Course. Language Research Society, 1(1), 41-46. https://doi.org/10.33021/lrs.v1i1.1038

Meisani, D. R. (2018). The Effectiveness of English Education at a Public Elementary School in Indonesia in Enhancing English for Young Learners. In The Tenth Conference on Applied Linguistics and The Second English Language Teaching and Technology Conference in collaboration with The First International Conference on Language,Literature, Culture, and Education (CONAPLIN and ICOLLITE) (pp. 80-85). https://doi.org/10.5220/0007162400800085

Muchtar, F. Y., Nasrah, \& Ilham, M. (2021). Pengembangan Multimedia Interaktif Berbasis ISpring Presenter untuk Meningkatkan Keterampilan Berpikir Kritis Siswa Sekolah Dasar. Jurnal Basicedu, 5(3), 1683-1688.

Nufus, T. Z. (2019). Teaching English to Young Learners in Indonesia (Pros and Cons). English Language in Focus (ELIF), 1(1), 65. https://doi.org/10.24853/elif.1.1.65-70

Nurmala, S., Triwoelandari, R., \& Fahri, M. (2021). Pengembangan Media Articulate Storyline 3 pada Pembelajaran IPA Berbasis STEM untuk Mengembangkan Kreativitas SiswaSD/MI. Jurnal Basicedu, 5(6), 5024-5034.

Prahani, B. K., Utama Alan Deta, Mochammad Yasir, Sri Astutik, Paken Pandiangan, Sayidah Mahtari, \& Husni Mubarok. (2020). The Concept of "Kampus Merdeka" in Accordance with Freire's Critical Pedagogy. Studies in Philosophy of Science and Education, 1(1), 2137. https://doi.org/10.46627/sipose.v1i1.8

Prihatin, Y. (2017). the Removal of English Language for Elementary School in Curriculum 2013. Dialektika Journal, 3(1), 53-68. Retrieved from https://journal.peradaban.ac.id/index.php/jdpbi/article/download/63/59/

Sanjadireja, R. R. (2020). Subtitle in Teaching Pronunciation with Video. IJET (Indonesian Journal of English Teaching), 9(1), 67-85. https://doi.org/10.15642/ijet2.2020.9.1.67-85

Sari, N., Suryanti, K., \& Manurung, S. M. (2017). Analisis Penggunaan Media Pembelajaran Untuk Meningkatkan Motivasi Peserta Didik Terhadap Pembelajaran Fisika Kelas XI MIPA 1 SMA Titian Teras Muaro Jambi. Jurnal Pendidikan Fisika Dan Keilmuan(JPFK), 3(2), $110-112$.

Sepyanda, M. (2017). The Importance of English Subject in Elementary School Curriculum. English Language Teaching and Reserach, I(1), 206-216.

Simanullang, M. (2018). The effect of applying video on the Students' English Pronunciation 
Accuracy at the Fifth Semester Students at the English Study Program of the Teacher's Training and Education Faculty the University of Sisingamangaraja XII Tapanuli in Academic Year 2018/2019. International Journal of English Literature and Social Sciences, 3(6), 1000-1007. https://doi.org/10.22161/ijels.3.6.13

Simatupang, E., \& Yuhertiana, I. (2021). Merdeka Belajar Kampus Merdeka terhadap Perubahan Paradigma Pembelajaran pada Pendidikan Tinggi: Sebuah Tinjauan Literatur. Jurnal Bisnis, Manajemen, Dan Ekonomi, 2(2), 30-38. https://doi.org/10.47747/jbme.v2i2.230

Sundari, F. S., \& Muliyawati, Y. (2017). Analisis Keterampilan Dasar Mengajar Mahasiswa PGSD. Pedagonal : Jurnal Ilmiah Pendidikan, 1(1), 26-36.

https://doi.org/10.33751/pedagog.v1i1.225

Surbhi, S. (2017). Difference Between Print Media and Electronic Media. Retrieved May 2, 2019, from https://keydifferences.com/difference-between-print-and-electronic-media.html

Utami, L. P. R. A., Suwastini, N. K. A., Dantes, G. R., Suprihatin, C. T., \& Adnyani, K. E. K. (2021). Virtual reality for supporting authentic learning in 21-st century learning. Jurnal Pendidikan Teknik Dan Kejuruan, 18(1), 132-141. Retrieved from https://ejournal.undiksha.ac.id/index.php/JPTK/article/viewFile/32376/17649

Veldman, M. A., Doolaard, S., Bosker, R. J., \& Snijders, T. A. B. (2020). Young children working together. Cooperative learning effects on group work of children in Grade 1 of primary education. Learning and Instruction, 67(July 2019), 101308.

https://doi.org/10.1016/j.learninstruc.2020.101308

Wulandari, R. M., Widyaningrum, L., \& Arini, L. D. D. (2021). Pengaruh Inovasi Cerdas pada Sistem Muskuloskeletal melalui Media Pembelajaran Interaktif di. Jurnal Basicedu, 5(3), $1683-1688$.

Yildirim, B., Topalcengiz, E. S., Arikan, G., \& Timur, S. (2020). Using Virtual Reality in the Classroom : Reflections of STEM Teachers on the Use of Teaching and Learning Tools Using Virtual Reality in the Classroom : Reflections of STEM Teachers on the Use of Teaching and Learning Tools. Journal of Education in Science Environment and Health, 6(3). https://doi.org/10.21891/jeseh.711779

Zamzami, M. A. (2019). A STUDY OF THE TEACHING ENGLISH FOR YOUNG LEARNERS AT ISLAMIC ELEMENTARY SCHOOL ISLAMIYAH MALANG. Akademika : Jurnal Manajemen Pendidikan Islam, 1(1), 52-75. Retrieved from https://ejournal.iaiskjmalang.ac.id/index.php/akad/article/view/71 